У $\triangle K(\mathrm{UDC}) 172: 331.57$

DOI: $10.26565 / 2226-0994-2020-62-20$

Mark Omorovie Ikeke

\title{
THE PLACE OF AN ETHICS OF SOLIDARITY IN MITIGATING THE PROBLEM OF UNEMPLOYMENT IN SUB-SAHARAN AFRICA
}

\begin{abstract}
Sub-Saharan Africa like some other parts of the world is plagued by myriads of problems such as environmental degradation, climate change, illegal migration, human trafficking, terrorism, resources conflicts, bad and inept leadership, failing states, armed banditry, drug smuggling, youth restiveness, unemployment, etc. One of these problems, unemployment, has led to the devastation of many human lives and equally made some persons to live in a degrading manner that affects environmental resources. Unemployment is not simply about statistics or numbers but about actual human lives who are holders of rights and dignity. Unemployment can impede the exercise of human rights and prevent people from living meaningful lives. In spite of the region's enormous natural resources and human capital, unemployment remains drastically unabated. Why is this situation so? This situation is problematized here. Consequently, this paper critically and analytically examines this problem of unemployment in Sub-Saharan Africa in the light of an ethics of solidarity. The paper hermeneutically interprets the concepts involved in the study. The grave reasons for unemployment in the region will be examined with likely solutions. Besides these possible solutions, the paper sees the issue as also bordering on ethical realities. Many of the factors that cause employment borders on human behaviours and morality. There are ethical dimensions to the issue then. This is why the paper takes the vantage point of an ethics of solidarity to argue for an additional solution to the problem. This is equally the theoretical framework from which the problem of unemployment is examined. Living in solidarity makes individuals easily collaborate and overcome societal problems like unemployment. The paper finds that unemployment is a pervasive problem in the sub-continent and is causing grave consequences for both human lives and the environment. The paper concludes that an ethics of solidarity can help in mitigating the problem of unemployment in the sub-continent. And that when this is done it will help to create a happier and peaceful sub-continent.
\end{abstract}

Keywords: Ethics, solidarity, unemployment, employment, Sub-Sahara Africa.

\section{Introduction}

Unemployment is a reality in many parts of the world especially in the Global South. The situation of unemployment in Sub-Saharan Africa (SSA) is grave and troubling as it impacts negatively on human life and the natural environment. The term "Sub-Saharan Africa" has multivariate meanings but in general it refers to the countries in Africa lying roughly below the Sahara Desert. The most recent unemployment ratio for the year 2019 in SSA is 6.5 [World Bank, 2020]. Going backward, the unemployment rates are as follows: 2018, 6.2; 2017, 6.3; 2016, 6.1; 2015, 5.8; 2014, 5.7; 2013, 5.7; 2012, 5.8; 2011, 5.5; 2010, 5.9 [World Bank, 2020]. For some selected countries in that 2019 it is as follows: Angola, 6.9; Botswana, 18.2; Burkina Faso, 6.3; Nigeria, 8.1; Cabo Verde, 12.2; Comoros, 4.3; Democratic Republic of Congo, 4.2; Congo Republic, 9,5; Equatorial Guinea, 6.4; Eritrea, 5.1; Eswatini, 22.1; The Gambia, 9.1; Kenya, 2.6; Lesotho, 23.4; Malawi, 5.7; Mauritius, 6.7; Mozambique, 3.2; Namibia, 20.3; Somalia, 11.1; South Africa, 28.2; South Sudan, 12.2; Zambia, 11.4; and Zimbabwe, 5.0 [World Bank, 2020]. This paper is a moral philosophical appraisal on the need to curb unemployment in SSA and it proposes using the ethics of solidarity as a key to support other efforts already in existence. The paper will not burden itself with statistical analyses as that is not the focus of the paper. It is enough to know that there is unemployment in the region as the World Bank indicates. The moral obligation to curb it is the concern here.

(C) Ikeke M. O., 2020.

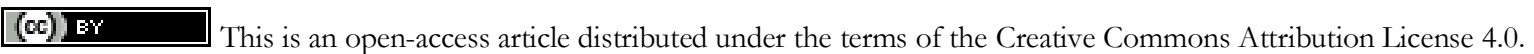


Beyond the statistical numbers is the reality that it is human beings and human lives that are spoken of in the above data. Unemployment is morally unacceptable as it harms human life and can precipitate the degradation of the environment. The task of this work is to critically examine and analyse the situation of unemployment in the subcontinent. Unemployment is on the rise [World Bank, 2020] and this should be a concern to all as it carries a lot of grave consequences. Why is it that unemployment continues as a problem in the subcontinent with its enormous natural wealth and human capital? Some of the key factors will be examined in this work. In order to achieve the goal of this paper, it shall make some clarification of the concepts of solidarity, ethics of solidarity and unemployment. The meaning of an ethics of solidarity is offered as it is the theoretical frame to examine the problem of unemployment. The argument is that when individuals and groups in society and in this subcontinent ethically cooperate, collaborate and collectively stand in solidarity with one another and those unemployed, the problem will be drastically mitigated. In solidarity the well-to-do of society will show concern for others and problems like corruption will be solved. The paper equally looks at the challenges of unemployment in the light of its negative effects or consequences on the subcontinent. Subsequently, the ethics of solidarity will be applied to the situation of unemployment. Thereafter a conclusion is made. It is proposed here that an ethics of solidarity can be used to curb unemployment and create a peaceable and healthy subcontinent.

\section{Conceptual Analysis}

The word, "ethics" like many other terms lacks a univocal definition. This notwithstanding many of the definitions shares a lot of similar ideas. It could be defined as: "the branch of philosophy which deals with the morality of human actions; or as the branch of philosophy which studies the norms of human behaviour" [Omoregbe, 1993, pp. 1-2]. From another point of view, it is the rational science of what goodness is and what constitutes evil human actions [Garret, 1968, p. 2]. Ethics is a science of ought that propose what human beings need to do. Notably, not every form of human behaviour is acceptable. There is right and there is wrong. Human beings are moral beings and their actions can be judged by the same human community. Ethics has both theoretical and practical aspects while at the same time taking into consideration its normative stance; and its practical dimensions, you have applied ethics like medical ethics, business ethics, social ethics, and political ethics [Ekei, 2001, p. 55].

Ethics ascertains, measures, and looks at human behaviour in terms of what is right or wrong following a standard of morality. While it is true that there may be varieties of moral standards in various cultural groups, it is also true there are what have come to be recognized as universal standards for measuring human behaviours in a global world. The Universal Declaration on Human Rights, International Covenant on Civil and Political Rights, International Covenant on Social, Economic and Cultural Rights, Universal Islamic Declaration on Human Rights, Cairo Declaration on Human Rights in Islam and other human rights instruments are built on the basis that there is a common global ethic [Sullivan \& Kymlicka, 2007, p. VIII]. Based on this, nations or individuals can be held accountable for war crimes, crimes against humanity, etc. There are equally laws of war, regulations on the use of the world oceans, etc.

The concern of this paper is with the ethics of solidarity. Etymologically, the word, "solidarity" is derived from the Latin (Solidus) meaning "whole" or "total." In French, it is from "solidaire" which means "mutual support of members of a group or society" and it is a "form of collective responsibility" [Scholz, 2013, p. 4957]. People have used the term, "solidarity" in different ways. It was used as the name of the Polish Solidarity Movement, as the basis of the foundation of the European legal system, as meaning mercy or charity or compassion, as civic friendship, as the benevolence of the welfare state, and even as international workers' brotherhood [Głos, 2017, p. 7]. Banyertz distinguishes four types of solidarity: societal cohesion; social movement groups; welfare state distributive justice activities; and the one that binds and connects all humanity [Bayertz, 1999, pp. 3ff]. It should be realized that all forms of solidarity imply certain ethical responsibilities. 
Furthermore, while every culture will have its own forms of solidarity, in the western philosophical tradition it has roots in the Greek concept of civic friendship and communal living in the Judeo-Christian tradition which all emphasized metaphysical heroism and radical commitment to a higher human order that transcends biological conditions where interdependency promotes wider social relations and responsibility [Głos, 2017, p. 30]. Theories of solidarity can be found in Jean Jacques Rousseau, Auguste Comte, Emile Durkheim, Ibn Khaldun, Gould, Harvey, Karl Marx, liberation theology, Islam, the women's movement, various black movements for justice or civil rights, discussion on human rights and global justice, etc [Scholz, 2013, pp. 4957-4963].

From a liberation perspective, solidarity speaks of the reality that all human beings are interrelated inclusive of their social structures and welfare; and because of this there is a sustained concrete effort at accountability to others aimed at ending all oppressions [Hobgood, 2007, p. 1307]. She notes that it is important to be clear that solidarity is different and goes beyond the concept of altruism that is found in liberal theological ethics where the individual is perceived a solitary being unrelated to larger social systems leading to a split of the self from others [Hobgood, 2007, p. 1307]. Solidarity is grounded in seeing all human persons as inalienably tied up in a common human network of mutuality. In the famous words of the leader of the American Civil Rights Movement, "I am cognizant of the interrelatedness of all communities and states <...> Injustice anywhere is a threat to justice everywhere. We are caught in an inescapable network of mutuality, tied in a single garment of destiny. Whatever affects one directly, affects all indirectly" [King, 1963].

From an African traditional worldview, solidarity flows through the concept of communalism in which the individual is seen as a social being and people lived a life of "one for all" and "all for one." This is described by various concepts in the African universe such as Ubunthu (humanness), Ujamaa (brotherhood), and African Humanism.

What are some of the essential features of solidarity? One key feature of solidarity comes from the statement of a former Catholic pontiff who said solidarity
“... is not a feeling of vague compassion or shallow distress at the misfortunes of so many people, both near and far. On the contrary, it is a firm and persevering determination to commit oneself to the common good; that is to say to the good of all and of each individual, because we are all really responsible for all” [Paul, 1987].

By this he means that it is a virtuous attitude. It is not just something that comes and goes or rendering occasional charitable help to others. It is a firm inward disposition aimed at working for the betterment of others who are seen as part of the same common humanity. Another feature is that it is first and foremost an inward disposition and perception. It is an inner belief. Though human beings by their nature are social and political animals and so they should engage in relationship with others, if a person does not recognize this reality, it becomes difficult for the person to act for the good of others. If a person sees himself/herself as a solitary individual being existing for only his/her good, the person may likely not be moved to actions of solidarity. One then should recognize the reality of being in solidarity to act for solidarity. Holistic solidarity does not end here in mere appreciation of one as a being in solidarity. It moves beyond appreciation, words, or feeling for others to actual pragmatic actions for the good and wellbeing of others. True solidarity also recognizes that the human person is a part of the natural environment and so this provokes environmental concerns and commitment.

Solidarity means the world is one family and one human race. It is made of individuals and various groups of people but they are all part of the one family of humanity. It does not mean differences don't exist among people. But in spite of all the differences there are things that bind and hold humanity together to act concertedly in social justice and equity.

Solidarity is an ethics. Living in solidarity is the right thing to do and is a right human behaviour that fosters authentic humanity. The point to recognize here is that solidarity is 
an ethical demand and a moral responsibility. It flows first and foremost from the fact that all human beings share a common humanity. Though human beings are located in various particular places, there is one human race and one planet earth in which human beings are to share their lives. The fact of a common human existence emanates into solidarity. It is not something that one can free oneself from unless the person is opting for selfishness or rugged individualism. It should be asserted that,

"The attitude of solidarity is a 'natural' consequence of
the fact that a human being exists and acts together with
others. Solidarity is also the foundation of a community in
which the common good conditions and liberates
participation, and participation serves the common good,
supports it, and implements it. Solidarity means
the continuous readiness to accept and perform that part of
task which is imposed due to the participation as a member
of a specific community..." [Wojtyla, p. 47].

Solidarity is ethical in its essence for it affirms the value of humanity and it imposes moral duties arising from interdependence that all are responsible for all and human beings are to live safeguarding the dignity of others [Paul, 1987, par. 38]. Writing concern public health ethics, the following should be recognized:
"If I am healthy and you are sick, the appropriate response is not one merely of pity or even sympathy by me towards you, but rather seeing that there is a connection between us. Solidarity allows us to see that your condition is actually inextricably related to my condition. This is not merely because your condition might be a threat to me (due, for example, to contagion) but because our health states are interdependent in a far richer way" [Dawson \& Jennings, 2012, p. 77].

No one account of solidarity exhaustively treats the historical and sociology of the term. But it would be imperative to remark that: "As evinced by the variety of types of solidarity <...> the many different contexts" of the use of the term it always involves "positive obligations of collective responsibility" [Scholz, 2013, p. 4963]. The implication of solidarity from the preceding should be clear. Whatever affects others affects you. Taking the situation of unemployment in SSA, it should be of concern to all who are employed and those who have resources to help to actually help without conditions. It is the humanitarian thing to do.

With the concept of solidarity clarified, the paper now clarifies the meaning of unemployment. Unemployment is "... the state of not being employed in paid work, or self-employed, even though available for such activity" [Jary \& Jary, 2000, p. 654]. Unemployment is a situation in which a person who can work searches for work but is unable to find any [Encyclopaedia Britannica, 2020]. The Editors of Encyclopedia Britannica in the same place cited notes that for a person to be counted as unemployed the person must be searching for remunerable work and is an active member in the labour force. Unemployment rate or intensity is measured by "the ratio of the number of unemployed people to the total labour force, made up of those who are either employed or unemployed" [Umo, 2007, p. 627]. In simple terms, the unemployment ratio is calculated by dividing the total number of unemployed people by the total labour/work force, and then you multiply by 100 .

Various kinds of unemployment have been identified such as cyclical, frictional, and structural. In the market economy there are boom periods and also recession, and depression. During boom periods economic activities such as employment, output and the price of goods and services are moving upward, while in recession/depression they are in the decline. When there is a decline in economic activities; the unemployment rate increases as there is a decrease 
in economic activities as people find it difficult to find jobs while some may lose their jobs. For those who are unemployed in this season, we refer to the situation as cyclical unemployment. In 2020 as many economies in the world is battling the COVID-19 crisis it has led to cyclical unemployment as some have been dropped from their jobs and it is difficult for many to find paid employment. Frictional unemployment refers to a situation when as a result of lack of information there is a mismatch between job seekers and employers. In the process/timeframe of people seeking jobs and their finding it, there is frictional unemployment. If information were readily accessible it will help job-seekers to easily find work. Structural unemployment refers to a drastic and dramatic change in demand for the goods and services of an industry or even scientific and technological change. An industry that used to produce certain goods like desktops that are no longer in demand will lead to people losing their jobs. Adjusting to new technologies takes time, and in the meantime people's sources of income are affected.

\title{
The Problem of Unemployment in SSA
}

Under this section of the problem of unemployment, the paper will look at some causes of unemployment in SSA, some consequences and some possible solutions. This will ground proposing an ethics of solidarity to combat the problem. It should be clear that it is not practicable to examine all the causes, consequences and solutions to unemployment here. The focus here is to propose another additional solution, which is the practice of an ethics of solidarity to help solve the problem. The paper does not imply an ethics of solidarity is the only panacea to the problem.

With regard to unemployment in SSA it can be as a result of corruption, skills mismatch, underdevelopment, lack of adequate infrastructure to provide a conducive environment, lack of equal access to education, inadequate sophisticated technological skills, etc. If jobs are few and the people seeking jobs are more or people are not qualified technically for sophisticated jobs, there is bound to be unemployment [Chaturvedi, 2006, p. 313]. In SSA every year millions of young persons are turned out from the higher institutions but the jobs available are few. A cardinal factor mentioned above that has contributed to unemployment in SSA is massive corruption on the part of public officers. It should be rightly noted that:

\begin{abstract}
"The present economic circumstances of the low-income countries in Sub-Saharan Africa are marred with high youth unemployment rate owing to the activities of political leaders as a result of mismanagement of resources and adverse macro-economic policies of various governments, by not channeling human and natural resources into profitable investment that are needed to yield the maximum economic growth" [Ihensekhien \& Ozemhoka, 2017, p. 3].
\end{abstract}

Corruption has certainly led to the mismanagement of resources that could have been used to create jobs for the teeming young people coming out from the universities every year.
"Unemployment has dire consequences for the subcontinent.
These effects include: <...> higher incidence of poverty, ill-heath and death, demoralization and strained family relationships, for society as a whole they include the failure to realize the social investment in human capital made through the educational system, and a loss of tax revenue combined with increase outgoings in unemployment benefits that threaten the financing of others of the welfare state" [Abercrombie, Hill \&Turner, 2000, p. 367].

From these preceding effects, the consequences are immense. It equally has ripple effects for every part of society in SSA. Thousands of persons from SSA are frequently on the move to illegally cross the Mediterranean Sea to Europe in search of better economic opportunities 
because of unemployment in the subcontinent. Many have died in the Mediterranean Sea in the process of crossing. Militancy, violence, piracy and kidnapping in the region are partly traceable to unemployment. In Nigeria's Niger Delta, in the North East of Nigeria where Boko Haram in rampaging, in the Somali Coast and the entire Horn of Africa, the Democratic Republic of Congo, Kenya, Ethiopia, etc. jobless youths take to arms to make a living. They kill, maim others and take the properties of others in order to live. They engage in crime such as armed robbery, terrorist activities and suicide bombing which are harmful to the economies of SSA [Thensekhien \& Ozemhoka 2017, p. 3]. Unemployment produces anxieties as those who have lost their jobs search for new ones, creates financial worries due to loss of income, and precipitate psychological distress that can affect the health of people [Jary \& Jary, 2000, p. 655]. Unemployment is something mortal and denies human beings of their inalienable rights and degrades human dignity, deprives humans of economic support and can put them in crippling debts [Paul, 1990, p. 5]. Not to be left out is the fact also that unemployed people suffering from degrading poverty tend to live hazardously on nature as they exploit environmental resources to sustain themselves [Okoji, 1997, p. 388].

Some possible solutions among others to the unemployment problem are: entrepreneurship development and training in new skills, support for small and medium enterprise especially in the informal economy, equal access and provision of educational opportunities, fostering of traditional apprenticeship system, and promotion of an ethics of solidarity. Education should be orientated towards providing more entrepreneurial empowerment and skills. The educational systems in many countries in the SSA often are too theoretical whereas today's economies require many technical skills. This is why there is often a mismatch when graduates come out of the universities or other tertiary institutions. Manpower training programs should also be fostered for on-the-job training for job-seekers, including the offering of scholarship to enable employers engage unskilled people [Umo, 2007, p. 636]. Other policy options that can help in tackling the crisis of unemployment are: provision of labour market information, regulation on labour mobility, concerted industrialization, subsidy to employers of labour, promotion of small and medium-scale enterprises, and encouragement of self-employment [Umo, 2007, pp. 638-640]. Some youths in SSA entered higher educational institution with a white-collar-job mentality, implying that after their graduation the government or one private employer will put them in an air-conditioned office to work. On graduating and they don't find an office like that they get disillusioned and unhappy. Some remain unemployed as they are not willing to work in the agricultural, manufacturing and mining industry. Beyond all these the value of the collaborative ethics of solidarity is vital. And this is what the next section is concerned with.

\section{Using an Ethics of Solidarity to Mitigate the Problem of Unemployment}

Writing of the implication of solidarity to persons gathered at the World Meeting of Popular Movements, the current Catholic pope states profoundly thus:

"It is a word that means much more than some acts of sporadic generosity. It is to think and to act in terms of community, of the priority of the life of all over the appropriation of goods by a few. It is also to fight against the structural causes of poverty, inequality, lack of work, land and housing, the denial of social and labor rights. It is to confront the destructive effects of the empire of money: forced displacements, painful emigrations, the traffic of persons, drugs, war, violence and all those realities that many of you suffer and that we are all called to transform. Solidarity, understood in its deepest sense, is a way of making history, and this is what the Popular Movements do" [Francis, 2014]. 
Beyond the consequences of employment mentioned above, the fact is that unemployment is a developmental issue. It is a problem that if not tackled leads to massive underdevelopment. Many unemployed persons cannot contribute fully and meaningfully to society. In a situation of unemployment some live in dehumanizing poverty as they cannot find remunerable work to do. They become dependent on others for survival and to provide for their basic needs such as food, shelter and clothing. It becomes difficult for them to fully exercise their civic and democratic rights. Suffering from hunger and poverty as a result of unemployment, some unemployed persons don't border about their political participation. The consequences of unemployment examined above reveals that unemployed people are affected mentally and physically in their health as they lack income to take care of these needs. They become deprived of what they are entitled to as a result of their having human dignity and inestimable worth. This is a fundamental reason why unemployment should be a serious concern not only for economists, those in governments, political scientists but indeed all persons in society. Philosophers have a duty to critically reflect on this serious issue of political economy.

As a social animal, one of the realities that define a human person is work. Work is important for fulfilling destiny. Through work the human persons create themselves and the world. They discover, explore and build the world. To be denied or deprived of work is to be denied of an important aspect of human existence. In the encyclical "The Priority of Labour," it is revealed that work is an essential aspect of human existence and human beings need it to flourish [Paul, 1981]. Work is not something extraneous to human existence. When someone is employed, Joda avers that it boosts self-esteem, enhance social identity and status, and foster social contact necessary for human existence [Jary \& Jary, 2000, p. 654]. Every human being has a right to work and protection against unemployment [United Nations, 1948; African Union, 1981]. These human rights instruments also place an obligation on States to ensure that individuals enjoy these rights. Unemployment then is a question of ethics and morality. Without people having work that enables them overcome unemployment, their lives and dignities are endangered. States have a duty in solidarity to help end unemployment in their countries.

The fact is that unemployment impedes the exercise of the human right to work and the pursuit of happiness. There is a moral obligation placed upon governments in SSA to ensure they provide or help people find work. Besides government, individuals and other groupings have an obligation arising from solidarity to work to end the problem of unemployment. Traditional systems of apprenticeship through which young people trained and then started their own businesses need to be continuously encouraged. Various civil society groups or non-governmental organizations set-up to train persons in entrepreneurial skills should not relent. The humanity and happiness of unemployed persons is at stake. When persons are gainfully employed they can contribute more meaningful to society and enhance their lives and that of their families. The question that someone may ask is, can an ethics of solidarity help to ameliorate the situation of massive employment in SAA? It certainly can. There are foundations such as the Tony Elumelu Foundation, the Dangote Foundation, Hand in Hand International, the Rockefeller Foundation, Catholic Justice, Development and Peace and many others who have invested much into solving the problem of unemployment in SSA. These are all rooted in a spirit of solidarity, philanthropy, humanitarianism, and communalism. Many of the founders and operators of these foundations and groups are equally driven by the spiritual values of their religions that teach love for others, benevolence, magnanimity, and hospitality to others.

The ethics of solidarity requires social concern and action on the part of each individual for others. Traditional African morality valued the spirit of communalism, Ubunthu (humanness), and Ujamaa (brotherhood). Nyerere, a former president of Tanzania rightly notes that in traditional African societies even when some persons could not work or cannot find work, people came to their aid to ensure that they don't go hungry [Nyerere, 1968, pp. 12-15]. It is painful to note that this value is fast eroding as some persons in Africa now have become individualistic and self-centered. Lacking an ethics of solidarity, you see politicians and others in public office in SSA corruptly enrich themselves with public money. Money that should have 
been used to create jobs for the unemployed is stolen and banked away in western countries. There is need for revival of authentic altruism, solidarity, social love and communitarian spirit. The African doctrine of Umunthu (humanness or humanity) or Ubunthu is not different from an ethics of solidarity. Umunthu is an attitude that requires the rich helping the poor, being concerned for the welfare of others and furthermore, evils like unemployment, poverty, oppression, war, etc militate against Umunthu [Sindima, 2016, p. 31]. Umunthu is African solidarity that shows in mutual understanding, caring, empathy, sharing, redistribution and support [Mawere \& Mubaya, 2016, p. 102]. Proposing an ethics of solidarity then to combat the problem of unemployment in SSA is not something foreign to the subcontinent. It consolidates values that are already present there among the people.

An ethics of solidarity as conceived in this paper finds grounding in other similar ideas and concepts such as moral cosmopolitanism, communitarianism, and philanthropism, and humanism. All these affirm the fact of a common humanity. These show that an ethics of solidarity is not a solitary idea but finds footing in other ideologies and systems of thought already. All this give credence to the reality that an ethics of solidarity is valuable and worthwhile. A moral cosmopolitan outlook sees others even if they are not of one's nationality irrespective of race, religion, gender, ethnicity and caste as part of one's humanity and willingly comes to the aid of the oppressed and suffering, and gives aid and care to stop such suffering and pain [Hooft, 2009, pp. 83-84]. The ethics of solidarity can profit from the thesis of responsibility that is found in moral cosmopolitanism. Remarkably, cosmopolitanism is a thesis about responsibility and guides the individual outwards to embrace a moral obligation to help others beyond one's nation [Brock \& Brighouse, 2005, p. 3]. In a place like SSA, a moral cosmopolitan will argue for helping to end the problem of unemployment in the subcontinent. Those who can are required to help. It is immoral to stand by and refuse to help ending the problem of unemployment if one can. It is a humanitarian problem because it is human worth and value that is at stake. Unemployed people can lose a sense of their dignity and develop low self-esteem and fall into depression. It is a public health issue. It should be securitized as it can precipitate insecurity. Unemployment causes youth restiveness. Individuals and groups in the countries of SSA should look beyond their own nations and work to achieve gainful and full employment for the entire unemployed of the subcontinent. Think and feel beyond your nation [Cheah \& Robbins, 1998, p. I]. There are many wealthy persons in the subcontinent. Their wealth if used for others in their nations and transnational can be channeled to end this problem of unemployment. That is a practice of an ethics of solidarity. It is the case that to a certain degree there is a mismatch of skills among graduates in SSA. Rather than waiting for governments in the spirit of solidarity to changing the plight of the unemployed, others can help in retraining and education of graduates to acquire new and updated skills to get gainfully employed. How to channel the knowledge acquired in a degree programs into employable skills is necessary in the subcontinent? The ethics of solidarity demands action such as promoting justice, ending inequalities and unjust disparities, helping the needy such as the unemployed, improving the national economy to make it conducive for people to find work, the influential and the wealthy helping the unemployed and promoting the human right to work [Paul, 1987]. It is imperative to remark that, "The unemployed and their families have a right to the effective solidarity of the State, of business interests and of worker's organization themselves" [Paul, 1990, p. 5].

The ethics of solidarity is not limited to people in SSA coming to help themselves in combating the scourge of unemployment. It requires global solidarity on the part of the nations of the North towards the Global South, of which SSA is a part. Some authors have rightly noted that the devastating exploitation of the Global South through slavery, colonialism, and now the attendant problem of globalization continue to affect the region. Much of the financial wealth of the world is in the rich nations of the North America and Europe, while millions of poor people in SSA and other regions of the South are facing massive unemployment and other development challenges [Hill, Knitter \& Madges, 2002, p. 151]. Global solidarity requires that 
the rich nations of the North continue to offer help to battle unemployment in SSA. This no doubt has been done through international government agencies such as USAID, Canadian International Development Agencies, UK Department for International Development, and many international non-governmental organizations such as The question that is worth asking which is not within the purview of this paper to discuss is, how effectively have the governments of SSA used these aids to eradicate unemployment? It is important to remark that an ethics of solidarity requires public action which requires standing beside those in need and also relationally "standing up for", "standing up with", and "standing up as" [Dawson \& Jennings, 2012, p. 74].

\section{Conclusion}

In summation, the paper in the preceding examined the problem of unemployment in SSA. In examining the problem, the paper examined the meaning of unemployment and types of unemployment. It also looked at the effect and possible solutions to the problem of unemployment. The paper preceded the examination of the problem of unemployment by making some conceptual clarifications of the concepts of solidarity, ethics, and ethics of solidarity, and unemployment. The ethics of solidarity was applied and proposed as useful in helping to tackle the problem of unemployment in the subcontinent. It was argued that solidarity places an obligation on the part of government, groups and other individuals to help tackle the problem of unemployment. While ethics of solidarity is not the only panacea to the problem, yet, it can help mobilize society to be concretely concerned about the problem of unemployment and work hard to eliminate it. With this done it will help to create a happier and peaceful society.

\section{REFERENCES}

Abercrombie, N., Hill, S., \& Turner, B. S. (2000). The Penguin Dictionary of Sociology. London: Penguin Books.

African Union. (1981). African Charter on Human and Peoples' Rights. Retrieved from https://au.int/en/treaties/african-charter-human-and-peoples-rights.

Bayertz, K. (1999). Four Uses of Solidarity. In K. Bayertz (Ed.), Solidarity (pp. 3-28). Dordrecht: Kluwer. DOI: https://doi.org/10.1007/978-94-015-9245-1.

Brock, G., \& Brighouse, H. (2005). Introduction. In G. Brock \& H. Brighouse (Eds.), The Political Philosophy of Cosmopolitanism (pp. 1-9). Cambridge: Cambridge University Press. DOI: https://doi.org/10.1017/CBO9780511614743.002.

Chaturvedi, A. K. (2006). Academic's Dictionary of Political Science. New Delhi: Academic (India) Publishers.

Cheah, P., \& Robbins, B. (Eds.). (1998). Cosmopolitics: Thinking and Felling Beyond the Nation. Minneapolis: University of Minnesota Press.

Dawson, A., \& Jennings, B. (2012). The Place of Solidarity in Public Health Ethics. Public Health Reviews, 34(1), 65-79. DOI: https://doi.org/10.1007/BF03391656.

Encyclopaedia Britannica. (2020). Unemployment. Retrieved from https://www.britannica.com/top ic/unemployment.

Ekei, J. C. (2001). Justice in Communalism: A Foundation of Ethics in African Philosophy. Lagos: Realm Communications.

Francis, P. (2014). Pope's Address to Popular Movements. Retrieved from https://zenit.org/articles/pope-s-address-to-popular-movements.

Garrett, T. M. (1968). Problems and Perceptive in Ethics. New York: Sheed \& Ward.

Głos, A. (2017). Solidarity in the Classical Tradition. Logos $i$ Ethos, 2(46), 7-33. DOI: https://doi.org/10.15633/lie.2359.

Hill, B. R., Knitter, P., \& Madges, W. (2002). Faith, Religion, and Theology: A Contemporary Introduction. Mystic, CT: Twenty-Third Publications.

Hobgood, M. E. (2007). Solidarity. In O. O. Espin, \& J. B. Nickoloff (Eds.), An Introductory Dictionary of Theology and Religious Studies (pp. 1306-1307). Collegeville, Minnesota: Liturgical Press. 
Hooft, S. V. (2009). Cosmopolitanism: A Philosophy for Global Ethics. Stocksfield, UK: Acumen.

Ihensekhien, O. A., \& Asekome, M. O. (2017). Youth Unemployment and Economic Growth: Lesson from Low-Income Countries in Sub-Saharan Africa. European Journal of Economics, Law and Politics, 4(2), 1-15.

Jary, D., \& Jary, J. (2000). Collins Internet-Linked Dictionary of Sociology. Glasgow, UK: HarperCollins Publishers.

King, M. L. (1963). Letter from a Birmingham Jail. Retrieved from https://www.africa.upenn.edu/A rticles_Gen/Letter_Birmingham.html.

Mawere, M., \& Mubaya, T. R. (2016). African Philosophy and Though Systems: A Search for a Culture and Philosophy of Belonging. Mankon, Bamenda, Cameroon: Langaa Research and Publishing CIG. DOI: https://doi.org/10.2307/j.ctvk3gkz5.

Nyerere, J. K. (1968). Ujamaa: Essays on Socialism. Dar es Salaam: Oxford University Press.

Okoji, M. A. (1997). Female Household's Heads in Ini: The Environmental Consequences of Poverty. In Poverty Alleviation in Nigeria: Selected Papers for the 1997 Annual Conference (pp. 383-396). Ibadan: Nigerian Economic Society.

Omoregbe, J. (1993). Ethics: A Systematic and Historical Study. Lagos: Joja Educational Research and Publishers.

Paul, J. (1978). Sollicitudo Rei Socialis. Retrieved from http://www.vatican.va/content/john-paulii/en/encyclicals/documents/hf_jp-ii_enc_30121987_sollicitudo-rei-socialis.html.

Paul, J. (1990). Address to the Workers at St. Margaret Square, Cottonera. L'Osservatore Romano, 5 (English Language Edition).

Paul, J. (1981). Laborem Exercens. Retrieved from http://www.vatican.va/content/john-paulii/en/encyclicals/documents/hf_jp-ii_enc_14091981_laborem-exercens.html.

Scholz, S. J. (2013). Solidarity. In H. LaFollette (Ed.), The International Encyclopedia of Ethics (Vol. VIII, pp. 4957-4964). Malden, MA: Wiley-Blackwell.

Sindima, H. J. (2016). Umunthu: The Ontology of African Ethics. In E. O. Gbadegesin, Y. K. Salami \& K. Abimbola (Eds.), Exploring the Ethics of Individualism and Communitarianism: Multidisciplinary Essays in Honour of Professor Segun Gbadegesin (pp.21-54). Mitchellvile, MD, USA: Harvest Day Publications.

Sullivan, W. M., \& Kymlicka, W. (2007). Table of Contents. In W. M. Sullivan \& W. Kymlicka (Eds.), The Globalization of Ethics (pp. VII-VIII). Cambridge: Cambridge University Press. DOI: https://doi.org/10.1017/CBO9780511498701.

Umo, J. U. (2007). Economic: An African Perspective. Lagos: Millennium Text Publishers.

United Nations. (1948). Universal Declaration on Human Rights. Retrieved from https://www.un.org/en/universal-declaration-human-rights.

Wojtyla, K. (1979). The Acting Person. (A.-T. Tymieniecka, Ed.; A. Potocki, Trans.). Dordrecht, Holland: D. Reidel Publishing. (Original work published 1969).

World Bank. (2020, June 21). Unemployment, Total (\% of Total Labor Force) (Modeled ILO Estimate) - $\quad$ Sub-Saharan Africa. Retrieved from https://data.worldbank.org/indicator/SL.UEM.TOTL.ZS?locations=ZG.

\section{Ikeke Mark Omorovie}

PhD in Philosophy, Associate Professor of the Department

of Religious Studies and Philosophy

Delta State University

P. M. B. 1, 330106, Abraka, Delta State, Nigeria

E-mail: Ikeke7@yahoo.com

ORCID: https://orcid.org/0000-0001-9115-378X

Article arrived: 30.05 .2020

Accepted: 19.06 .2020 


\section{МІСЦЕ ЕТИКИ СОАІААРНОСТІ В ПОМ'ЯКШЕННІ ПРОБАЕМИ БЕЗРОБІТТЯ В СУБСАХАРСЬКІЙ АФРИЦІ}

\section{Ікеке Марк Оморові}

Аоктор філософії, Аоцент кафелри релігієзнавства і філософії

Університет штату Аельта

П. п. с. 1, Абрака, 330106, штат Аельта, Нігерія

E-mail: Ikeke7@yahoo.com

ORCID: https://orcid.org/0000-0001-9115-378X

Суб̆сахарська Африка, як і деякі інші частини світу, стражАає від безлічі проб̆лем, як-от Аеградація навколишнього середовища, зміна клімату, немегальна міграція, торгівля Аюдьми, тероризм, конфмікти через ресурси, погане та невміле керівництво, неспроможні держави, збройний бандитизм, контрабанда наркотиків, молодіжні заворушення, безробіття тощо. ОАна 3 цих проблем, безробіття, зруйнувала багато Аюдських життів і рівною мірою змусила деяких Аюдей жити в принизАивий ААя АюАини спосіб, що також вПливає і на ситуацію 3 екологічними ресурсами. Безробіття - це не просто статистика чи цифри, але й фактичне життя Аюдей, які є носіями прав і гіАності. Безробіття може перешкоджати зАійсненню прав Аюдини та забирати в Аюдей можливість жити осмисленим життям. Незважаючи на величезні природні ресурси та Аюдський капітал суббсахарського регіону, безробіття вперто залишається на тому ж рівні. Тож чому ми маємо таку ситуацію? Саме це питання проблематизується в нашій роботі. Отже, запропонована стаття критично та аналітично розглядає проблему безробіття в Суб̆сахарській Африці у світлі етики соліАарності. Також у статті герменевтично інтерпретуються кАючові Аля такого АосліАження поняття. Ми розглядасмо фундаментальні причини безробіття в суб̆сахарському регіоні та аналізуємо можливі шляхи розв'язання цієї проблеми. У запропонованому АосліАженні проблема безробіття розглядається як така, що межує з етичною сферою, оскільки багато факторів, які забезпечують зайнятість, пов'язані з поведінкою та мораАлю АюАей. Тож у цьому питанні є етичні аспекти. Саме тому в нашому досліАженні ми займаємо позицію етики соліАарності: у такий спосіб ми намагаємось об̆грунтувати додатковий шлях вирішення проблеми безробіття. Інакше кажучи, це водночас і практична, і теоретична основа Аля розгляду проблеми безробіття. СоліАарне життя змушує мюдей мегко співпрацювати та долати такі соціальні проблеми, як безробіття. Отже, АосліАження в піАсумку піАтверАжує, що безробіття є поширеною проблемою на субоконтиненті та спричиняє серйозні наслідки як Аля життя Аюдей, так і Аля навколишнього середовища. У статті робиться висновок, що етика соліАарності може Аопомогти пом'якшити проблему безробіття на субконтиненті, зробивши його більш мирним і щасливим.

КАючові слова: етика, соліАарність, безробіття, зайнятість, Субссахарська Африка.

Стаття надійшла Ао редакції: 30.05.2020

Схвалено Ао Аруку: 19.06.2020 